$\xi=$

\title{
Deformability of Short Steel Reinforced Concrete Structures on Light Concrete
}

\author{
Oleksandr Semko ${ }^{1}$, Viktor Dariienko ${ }^{2}$, Vitaliy Sirobaba ${ }^{3 *}$ \\ ${ }^{1}$ Poltava National Technical Yuri Kondratyuk University, Ukraine \\ ${ }^{2}$ Central Ukrainian National Technical University, Ukraine \\ ${ }^{3}$ Poltava National Technical Yuri Kondratyuk University, Ukraine \\ *Corresponding Author E-Mail: Vitalij.Sirobaba@Gmail.Com
}

\begin{abstract}
The calculation, modeling and experimental research of steel-concrete tubular elements made of thin-walled galvanized sheet metal and lightweight concrete have been carried out. The proposed type of structures can be used as a separate structure in the form of a column or a pillar, and one of the types of the reinforcement of a certain light structure. The basic technological and constructive requirements for manufacturing and further exploitation of structures are given. For determination of actual work's indexes of constructions experimental research of standards are undertaken, and recommendations on adjustment of well-known calculation formulas of close constructions as for structural parameters are given. The design (modeling) was performed in MSC / Nastran software. An analysis of the proposed structures use is carried out with the corresponding conclusions.
\end{abstract}

Keywords: concrete filled steel tube, testing, modeling, polystyrene concrete.

\section{Introduction}

Scientific progress in the field of construction leads to the emergence of new and improved existing building structures. One of the trends of development is the search of new steel and concrete compounds, and their rational work, as a building structure. These structures include steel reinforced concrete, the design of which includes rolling or cold-formed steel profiles, bar reinforcement and concrete.

In construction practice there are widely used mixed systems, in which reinforced concrete flooring, slabs and other structures are installed on the steel bearing constructions. Combining them into an integral steel-concrete or steel concrete structure gives the opportunity to use the properties of steel and concrete more efficiently in many cases, to reduce costs of building materials, to increase economic efficiency.

One of the options is a combination of thin-walled sheet construction, lightweight concrete and a thin-walled steel profile (LSTK). This design takes into account the features of each material. It can be used both as a separate structure and for strengthening of metal light buildings supporting structures.

\section{Features of Work and Constructive Re- quirements for the Structures Construction}

\subsection{Requirements for a Steel Shell}

A thin-walled $(\mathrm{t}=0.42 \mathrm{~mm})$ galvanized sheet metal was used to make a light steel shell. According to the strength indicators, the steel profile is responsible for its mechanical properties of steel S350GD + Z. The use of galvanized steel solves the task of corrosion resistance of the outer shell, but it remains relevant how to protect the structure from temperature effects in the case of fires. The use of sheet steel gives the opportunity to make shells without transverse joints along the entire element, limited to the width of the rolled stock.

But the use of this type of metal causes the appearance of a joint seam along the entire structure. The seam is the weakest place in this shell. The connection must meet technological and constructive requirements. That steel is supposed to be galvanized, so most of welded joints are not appropriate due to the destruction of the zinc protective layer. Bolt connections are not feasible for technological reasons.

To solve this problem, it is suggested to use a double connection with falsification of subsequent riveting. The effectiveness of connections using is described [1].

The expediency of using this shell is characterized by the following features:

1. The working structure which can be included in the work either as a compressed element or in the form of concrete clips.

2. An excellent formwork for concreting.

3. Lightweight construction.

4. Corrosion protected metal.

5. Lightweight mounting.

The formed shell (Fig.1), working on the central compression, will quickly lose the local resistance by forming the grooves on the ends to form a corrugated surface. The solution of this task is the enhancement with light concrete.

Short tubular constructions with dimensions $h=400 \mathrm{~mm}$, $d=100 \mathrm{~mm}$, and designs with dimensions $h=1500 \mathrm{~mm}, d=100 \mathrm{~mm}$ have been made. 


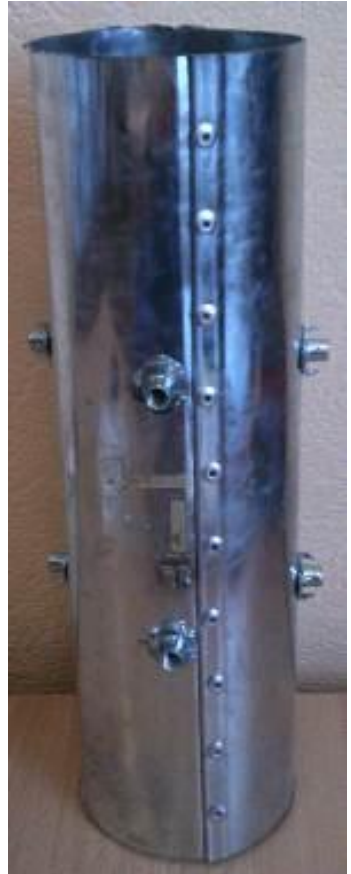

Fig. 1: Steel shell

\subsection{Requirements for Light Concrete}

In order to strengthen the steel shell it is suggested to use light polystyrene concrete, which filling the interior space of the structure, will increase the shell faces stability and the strength of the entire structure, taking the part of the load. Justification and the selection of light concrete [2] for this construction type was based on the selection of physical and mechanical characteristics to ensure normal work throughout the period of operation.

Characteristics of concrete samples were determined in two ways: a test of $100 \times 100 \mathrm{~mm}$ cubes and cylinders of $400 \mathrm{~mm}$ height and $100 \mathrm{~mm}$ in diameter (Fig. 2). The examples for the selection of concrete were manufactured in different density classes - from D300 to D-1000 in an amount not less than 3 pieces of each class. As the results of the test the average characteristics of each class of polystyrene concrete samples were determined. The main parameters for the selection of concrete were lightness, durability, and easy placement, so that this polystyrene concrete would be expediently used to enhance the newly formed constructions.

Technological peculiarities of polystyrene concrete production are due to the number of all components, according to the sequence of mixing and conditions for further reaching (strengthening, hardening) during 28 days.

The basic requirements for materials:

1. SDS is a mandatory additive which provides the concrete plasticity, increases the penetration of polystyrene filler and cement binder, forms micro pores that facilitate the construction.

2. Cement binders according to the cement brands M500 and more.

3. The use of career sand (cutter).

4. Pure water with low iron content.

The technology of manufacturing is: Soaked polysty-roll balls ( $d=$ $1-3 \mathrm{~mm}$ ) with solution of water and resin of wood-sapwood (SDS) are watered, then astringent on the cementious basis and the fine filler (sand) are gradually added. Everything is mixed up to the homogeneous concrete consistency and is arranged in the construction. Taking into account the effect of SDS action and cement binding time terms are limited, the full cycle of preparation and installation of concrete mix should not exceed 15-20 minutes. The heat-humidity regime is the same as for heavy concrete or under the following of conditions [3].

The results of the experimental researches are given in Table 1.
Table 1: Experimental researches

\begin{tabular}{|c|c|c|c|c|c|}
\hline \multirow{2}{*}{$\begin{array}{c}\text { Name of } \\
\text { samples }\end{array}$} & $\begin{array}{c}\text { Inten- } \\
\text { sion } \\
\mathrm{P}_{\mathrm{cr}}, \mathrm{KH}\end{array}$ & $\begin{array}{c}\text { Dimen- } \\
\text { sions of } \\
\text { sample, } \\
\mathrm{cm}\end{array}$ & $\begin{array}{c}\text { Weight } \\
\text { of sam- } \\
\mathrm{ple}, \mathrm{kg}\end{array}$ & $\begin{array}{c}\text { Vol- } \\
\mathrm{ume}, \\
\mathrm{cm}^{3}\end{array}$ & $\begin{array}{c}\text { Strength } \\
, \mathrm{f}_{\mathrm{c}}, \\
\mathrm{\kappa H} / \mathrm{cm}^{2}\end{array}$ \\
\hline \multirow{2}{\mathrm{C}10}{} & 32,56 & $10 \times 10 \times 10$ & 0,790 & 1000 & 0,0326 \\
\cline { 2 - 6 } $\begin{array}{c}\text { polysty- } \\
\text { rene roll } \\
\text { concrete) }\end{array}$ & 32,97 & $10 \times 10 \times 10$ & 0,762 & 1000 & 0,0330 \\
\cline { 2 - 6 } & 32,75 & $10 \times 10 \times 10$ & 0,782 & 1000 & 0,0328 \\
\hline $\begin{array}{c}\text { CC40 } \\
\text { (polysty- } \\
\text { rene roller- } \\
\text { concrete } \\
\text { cylinder })\end{array}$ & 18,56 & $40 \times 10$ & 2,390 & 3140 & 0,0236 \\
\cline { 2 - 6 } & 18,43 & $40 \times 10$ & 2,230 & 3140 & 0,0235 \\
\hline
\end{tabular}

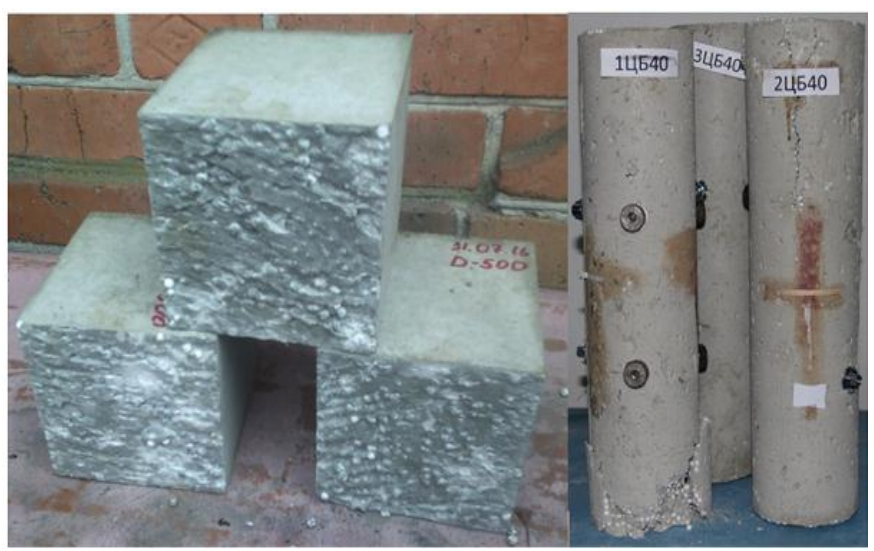

Fig. 2: Concrete samples

\subsection{LSTK Design}

LSTK profile is made of the same steel grade as the steel shell S350GD + Z.

The geometric dimensions of the profile are $L=400 \mathrm{~mm}$ and $L=1500 \mathrm{~mm}$. Profile $\Sigma 50 \times 30 \mathrm{~mm}$ (Fig. 3).

The profile is placed in a steel reinforced concrete structure with the wall in the opposite direction from the joint seam of the shell. It is connected with the rational distribution of stresses in the construction and the maximum reinforcement with concrete of the shell seam itself and the stability of the profile.

The work of the LSTK profiles varies with their complete concreting. It is considered that the non-reduced profile is cut but the full profile is cut too in the calculation and in actual work. That is, the flexible plates are not excluded from the work. The profile at maximum loads loses overall stability.

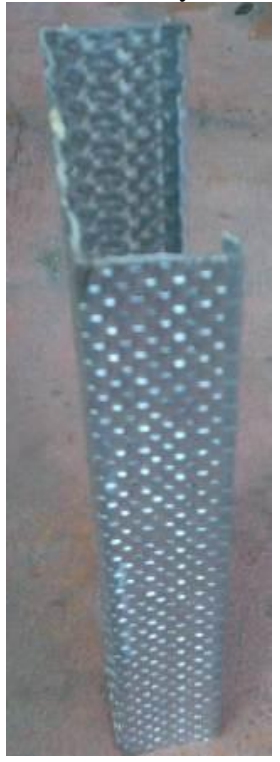

Fig. 3: LSTK profile 


\subsection{Steel Reinforced Concrete Constructions}

The research was carried out on three-component samples:

1. Concrete filled steel samples $\mathrm{L}=400 \mathrm{~mm}$ (steel cladding + concrete);

2. Concrete filled steel samples $\mathrm{L}=1500 \mathrm{~mm}$ (steel clip + concrete);

3. Steel reinforced concrete samples $\mathrm{L}=400 \mathrm{~mm}$ (steel clamp + concrete + LSTK profile);

4. Steel reinforced concrete samples $\mathrm{L}=1500 \mathrm{~mm}$ (steel clamp + concrete + LSTK profile); Each series of samples was made in the amount of 6 pcs. It is due to the division into different ways of applying effort. At each of the series there were not less than 3 samples for each type of loading.

The load was transferred to the entire section, to concrete and to concrete with LSTK profile. The rational selection of structural elements should reinforce the weaknesses of each of the materials, due to the correct load distribution (Fig.4).
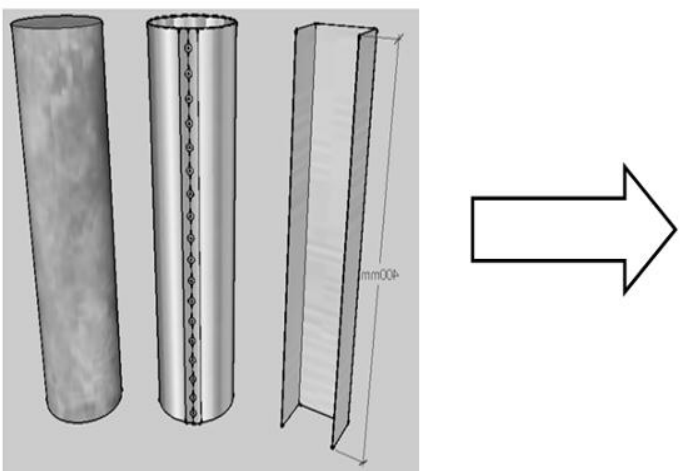

Fig. 4: Steel reinforced construction

\section{Analytical Calculation of Steel Concrete Structures}

In the analytical calculation of the samples load-bearing capacity, the combined work of the combined materials was not taken into account due to the lack of normative base as for the calculation of lightweight pipe concrete and reinforced concrete constructions. Therefore, it was decided in the first approximation of the analytical method to determine the critical effort of sample destruction as the total value of the destructive samples loading [4].

For simplification for members in axial compression, the design value of the normal force $\mathrm{N}_{\mathrm{Ed}}$ should satisfy [5]

$\frac{N_{E d}}{\chi N_{p l, R d}} \leq 1,0$

where:

$N_{p l, R d}$ - the plastic resistance design value of the composite section to compressive normal force [6];

$\chi$ is the reduction factor for the relevant buckling mode given in EN 1993-1-1, in terms of the relevant relative slenderness.

$N_{p l, R d}=A_{a} f_{y d}+A_{c} f_{c d}+A_{s} f_{s d}$

where:

$A_{a}$ - cross-sectional area of the structural steel section;

$f_{y d}-$ the yield strength design value of structural steel;

$A_{c}$ - cross-sectional concrete area;

$f_{c d}$ - the cylinder compressive strength design value of concrete;

$A_{s}$ - cross-sectional area reinforcement;

$f_{s d}-$ the yield strength design value of reinforcing steel.

These formulas should be adaptated for lightweight constructions Only after comparing them with experimental investigations such as the destruction nature, the determination of factors that reduce the overall structural strength it will be possible to determine the correct deduction of the working conditions' coefficients and the coefficient which considers the joint operation of these constructions.

For long patterns it is necessary to perform general and local stability tests [7].

\section{Experimental Researches}

Two methods that have different accuracy of measurements are used to measure the longitudinal deformations; they allow to reduce the probability of a large error and to trace both local deformations of the material on separate sections of the structure and general deformations of the sample as a whole at the different tests stages.

The first method is based on the determination of deformations with the help of clock-type indicators with a price of $0.01 \mathrm{~mm}$ on a $200 \mathrm{~mm}$ basis, which is installed on four sides of the construction, in two mutually perpendicular directions. The fixation is carried out using brackets, the basis of which (fastening nuts) is glued to the sample base.

The location of measuring devices is due to the nature of the deformation and sample destruction (Fig. 5).

The second method is the determination of longitudinal and transversal deformations with the help of strain gauge measurements of the ISU-3 device, the accuracy of which is $1 \times 10^{-5} \mathrm{~mm}$. In order to improve the accuracy of the strain gauges location, they were cleaned, degreased with acetone, and ground primer was applied to the BF-2 adhesive, and the strain gauges gluing on the sample was done in 24 hours. After complete adhesive polymerization, the strain gauges were checked with the electric multimeter DT838.

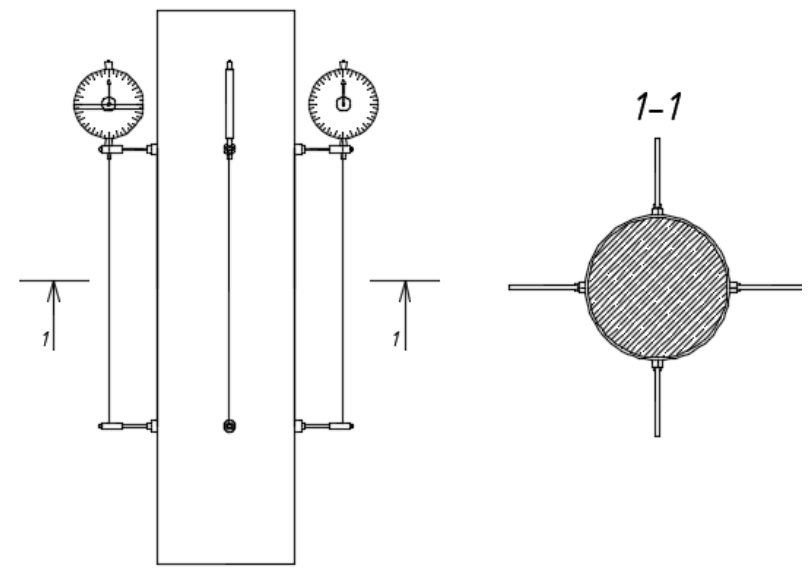

Fig. 5: The scheme of clock-type indicators arrangement on samples

Taking into account safety requirements and preventing short circuits, the connection of strain gauges and wires was carried out on dielectric paper and dielectric plates with adhesive BF-2. Different types of strain gauges were used for each material.

The strain gauges PKB $50 \mathrm{~mm}$ were used for concrete samples. The strain gauges 2 KKP-30-200gB were used for metal samples. The decisions taken on the application of strain gauges are due to the structure of the materials on which they were mounted.

The general deformation of the samples was controlled by a calibrated metal ruler with a price of $0.5 \mathrm{~mm}$.

Before the test, all the samples passed visual and in-situ control for the defects detection. Also all geometric and physical parameters of the samples are measured.

This article only shows critical effort and deformation of the destruction. The nature of samples destruction depending on the application of the load is different. The general patterns of samples deformation are shown in Fig. 6-10. 


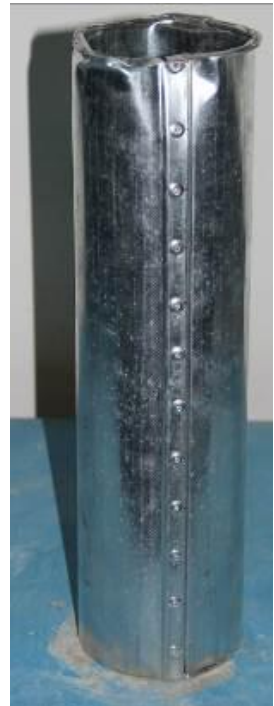

a) Steel shell

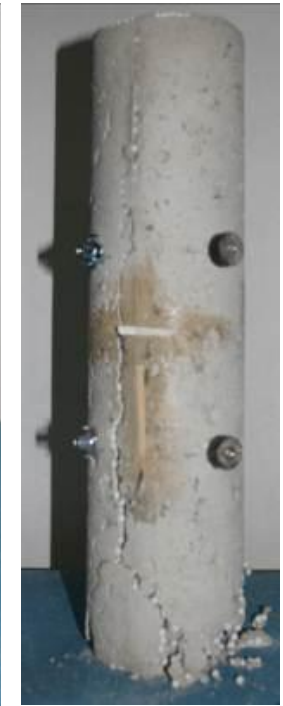

b) Polystyreneconcrete

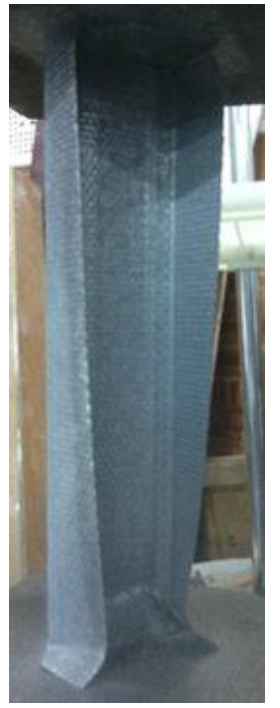

c) LSTC profile
Fig. 6: The destruction nature of each component of the construction: a) The steel shell has lost local resistance in the supporting areas, the further destruction of the sample is done in the way of metal corrugation for an average of $10 \mathrm{~mm}$.

b) The destruction of the concrete sample is done at the supporting area, with a sample deformation of $15 \mathrm{~mm}$, there were longitudinal cracks in the element.

c) The LSTC profile has lost its local stability in the supporting areas with large deviations from the central axis of the structure.

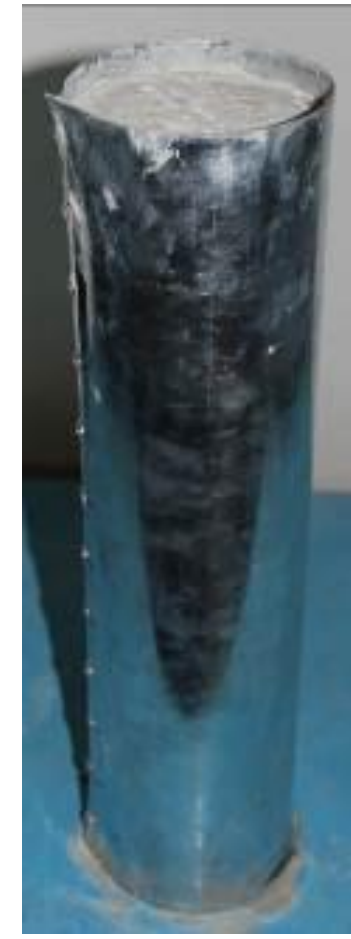

a) Load on concrete

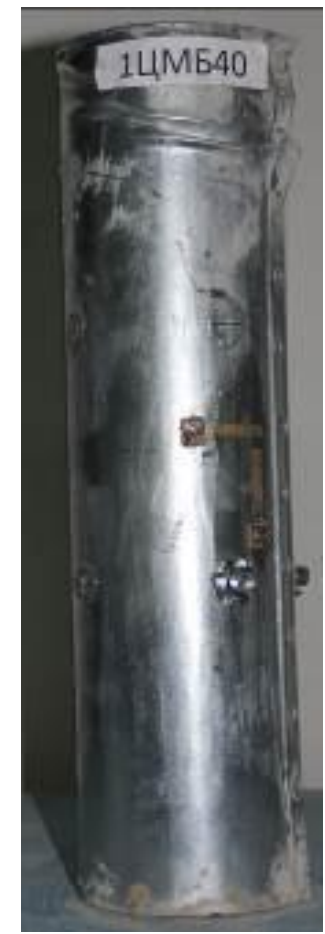

b) Load over the entire section
Fig. 7: The destruction nature concrete filled steel structures $L=400 \mathrm{~mm}$

a) During the compression of concrete there is the disclosure of the shell connection, such as the cutting of rivets. Disclosure begins at the supporting area.

b) The destruction of the sample is done in the view of the local loss of shell stability with the first corrugated bend on $10 \mathrm{~mm}$ and the other ones with the step of connecting rivets. There is corrugation as a result of the concrete core destruction.

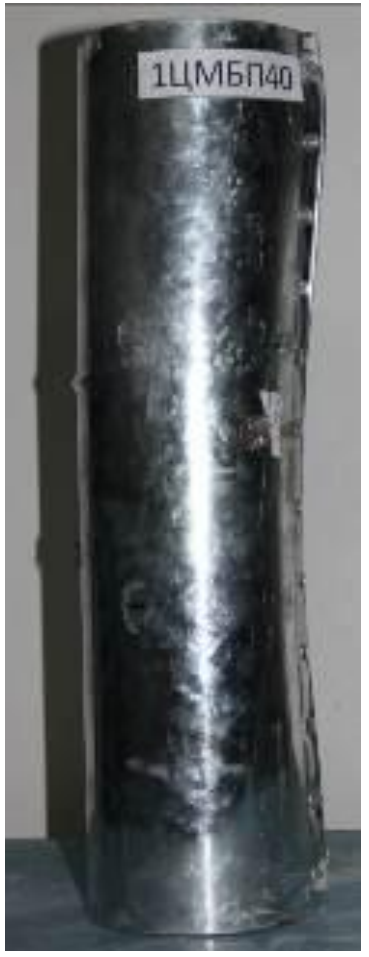

a) Load on concrete

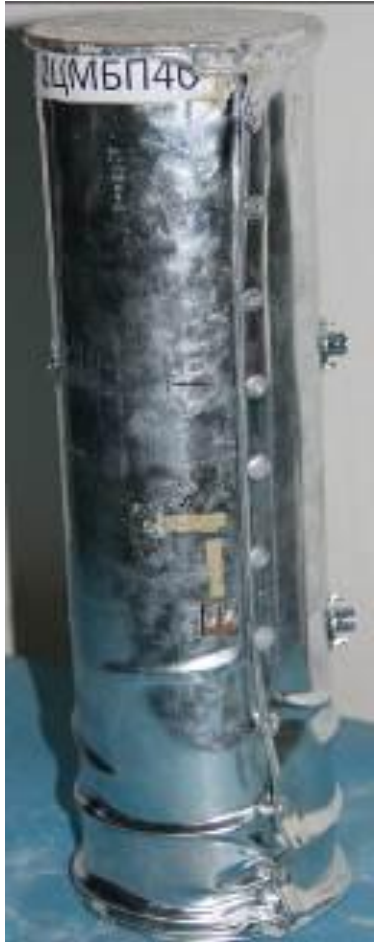

b) Load over the entire section
Fig. 8: The destruction nature of steel reinforced concrete structures $L=400 \mathrm{~mm}$

a) The deformation of the sample is done with the general loss of stability. Almost in the middle of the sample there was corrugation. The connection was opened at the supporting areas. A characteristic general deviation of the structure from the central axis was observed. These deformations are caused by the general loss of stability of LSTK profile in the middle of the sample.

b) The deformation of the sample is done with the general loss of stability. The first corrugated formations were on the supporting area, then in the middle of the sample, the further corrugation formation was extended from the supporting areas to the middle of the element with the step of riveting joints. General deformation is caused by the loss of the overall stability of the LSTK profile and the attachment of concrete trowel.

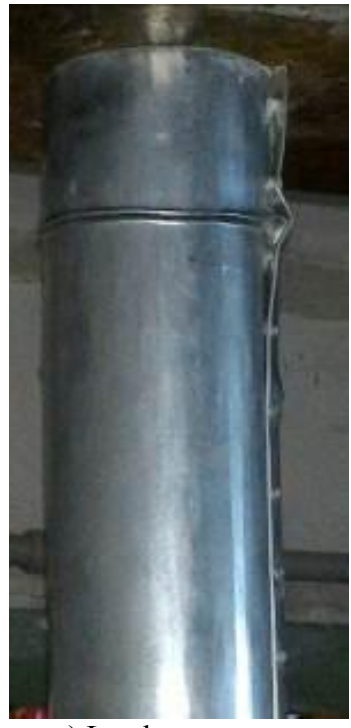

a) Load on concrete

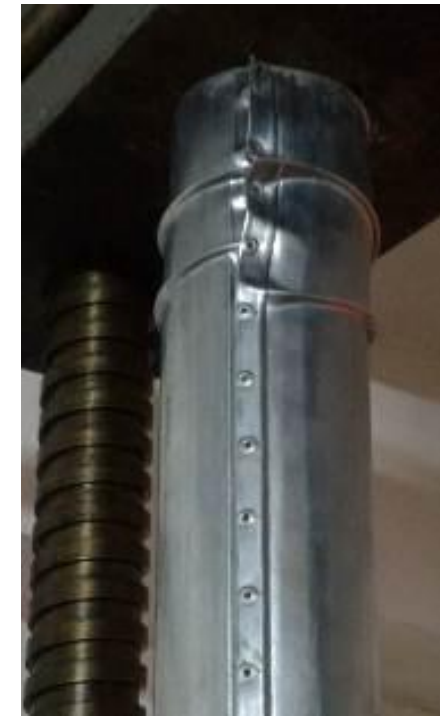

b) Load over the entire section
Fig. 9: The destruction nature of concrete filled steel structures $L=1500 \mathrm{~mm}$

a) During the concrete compression there is the disclosure of the shell connection, such as the cutting of rivets. Disclosure begins at the supporting area. The first corrugated formation appears at the distance of $100 \mathrm{~mm}$. 
b) The destruction of the sample is done in the view of the local loss of shell stability with the first corrugated bend on $10 \mathrm{~mm}$ and the other ones with the step of connecting rivets. Corrugation is the result of the concrete core destruction.

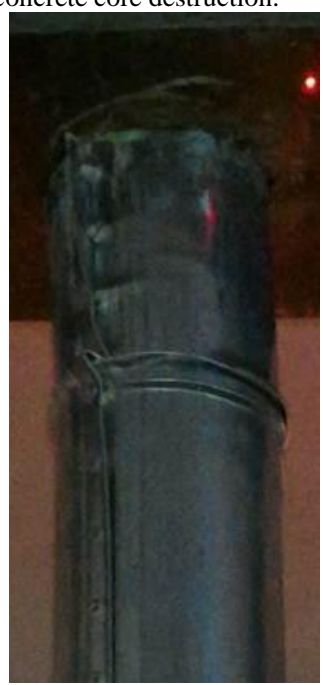

a) Load on concrete

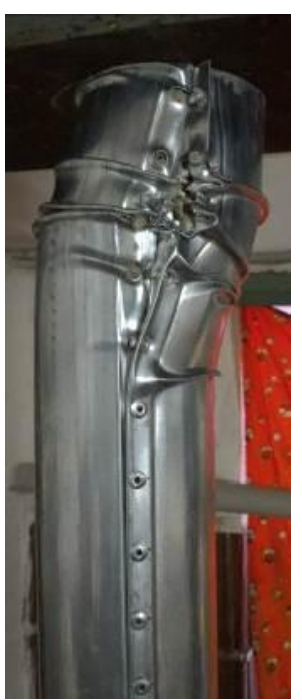

b) Load over the entire section Fig. 10: The nature of the destruction of steel reinforced concrete structures $\mathrm{L}=1500 \mathrm{~mm}$

a) The sample deformation is done with the loss of structural stability in the upper part of the sample. There is corrugation at a distance of 300 $\mathrm{mm}$ from the porous part of the sample. The rotation of the connection is on the supporting areas. There was a characteristic general deviation of the structure from the central axis. These deformations are caused by LSTK profile loss of stability.

b) The deformation of the sample is done with the loss of structural stability at the sample top. The first corrugated formations appeared at the supporting area, then at a distance of $300 \mathrm{~mm}$. The further formation of the corrugation was extended from the supporting area to the middle of the element with the step of riveting joints. General deformation is due to the LSTK profile loss of stability and the adherence of concrete trowel.

\section{Numerical Modeling of Samples}

Multiple modeling of the stress-strain condition of pipe concrete structures is performed in NASTRAN Femap 10.1.1 SC 32bit system. The modeling main purpose is to achieve the closest description of the structure's work in comparison with the experimental results [8].

To create of a finite-element model for determining the stressstrain condition of steel-concrete structures models and their analysis in an elastic stage of work was carried out in the following order [9]:

- the choice of coordinate system;

- creation of model geometry. The volumetric model was formed by extending the plane boundary surface, which was pre-made according to the given lines to the required height;

- introduction of materials properties [10]. Materials of the model were separately as isotropic. The value of physical-mechanical characteristics of the materials (elastic Young's modulus $E$ and the coefficient of transverse deformation $v$ ) and the deformation law $(\sigma-\varepsilon)$ were taken as a result of the experimental work (see paragraph 4 of this paper). The third constant is the shear modulus $G$ was determined automatically by the known correlation between $E$ and $v$;

- the choice of finite elements type and the division of the model into finite elements. The choice of the type and size of volumetric finite elements was influenced by the time of creating a bulky finite element, the required disk space for the NASTRAN calculation, the accuracy and convergence of the results obtained when calculating the models of broken finite elements. The comparison of the effectiveness of finite elements size and type is shown in Fig. 11. As the results of the analysis, three-dimensional bulk solids like hexahedrons were used to create a bulk finite elemental grid of samples.

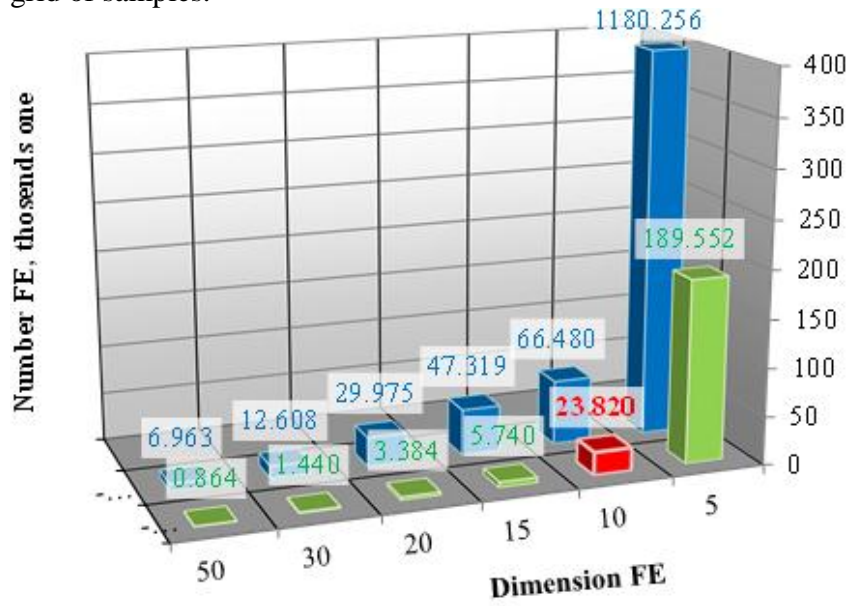

Fig. 11. Comparison of the effectiveness of finite elements size and type

- the setting of boundary conditions (degrees of freedom) - the joints applied to the structure and formation of the system onloads and the setting of their values [11];

- correctness verification of the developed model;

- choice of type of finite element analysis and structure's calculation - finite element analysis. Two types of calculation were completed.

A) Nonlinear static analysis is the basic type of analysis, which takes into account the predefined functional dependencies of the work of materials (diagrams $\sigma-\varepsilon$ ). The results of this type of analysis were used to compare the stress-strain condition of models with experimentally tested structures.

B) the calculation of stability was carried out in order to determine the form of stability loss of the flexible elements;

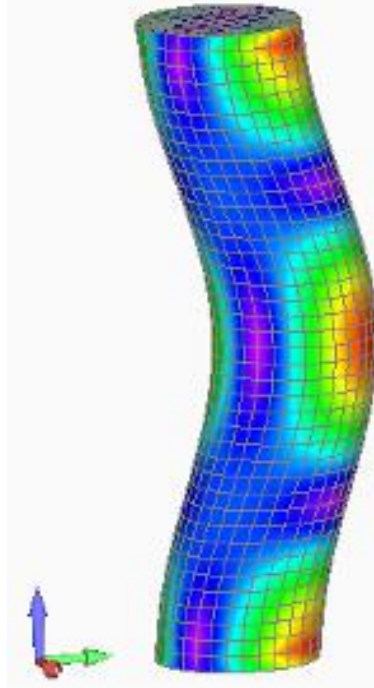

a) Load on concrete

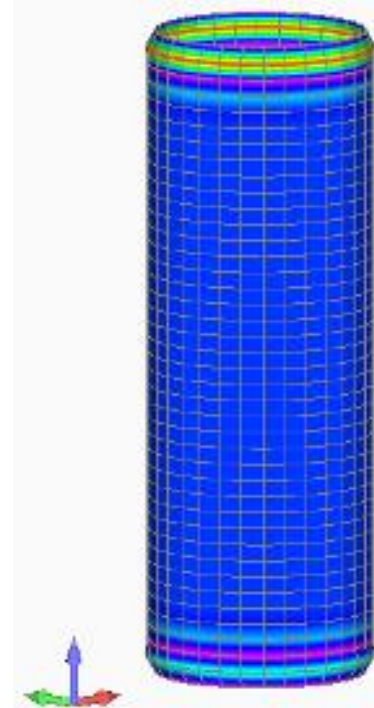

b) Load over the entire section
Fig. 12: The deformation nature of models of steel-concrete structures $L=400 \mathrm{~mm}$

- analysis of calculations results and their presentation for practical use. The sketches of models deformation after finite element analysis, as well as the distribution of stresses on their surfaces are shown in Fig. 12-13. The pattern of models deformation is similar to the destruction nature of experimentally tested samples, as shown in Fig. 6-10. Thus, the modeling of the stress-strain condition of the design models allowed identifying places with maximum stresses and deformations, which must first be paid special attention during the conduct of experimental researches. 


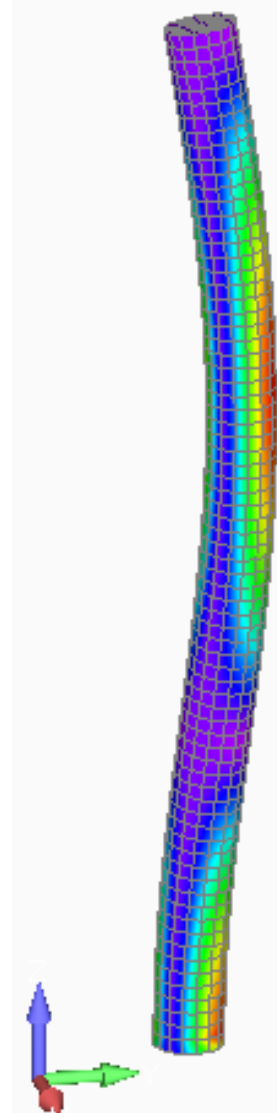

a) Load on concrete

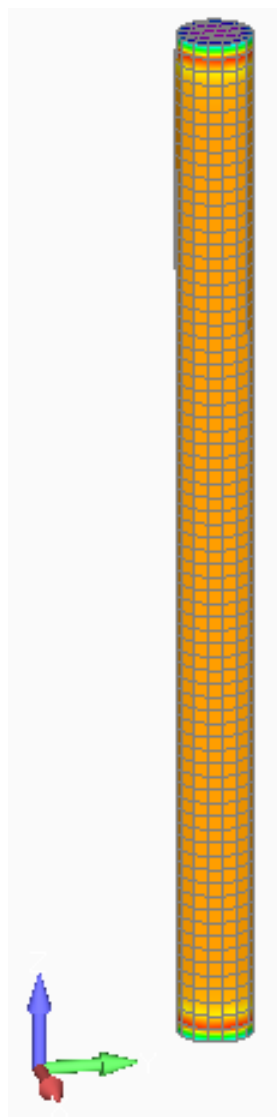

b) Load over the entire section

Fig. 13: The pattern of deformation of steel reinforced concrete structures $\mathrm{L}=1500 \mathrm{~mm}$

\section{Conclusion}

The difference between experimental and analytical methods of calculation proves the joint work of the used materials, each of which reduces the disadvantages of another. According to the results of the experimental researches it can be noted that the effectiveness of using these structures is significant within $8-25 \%$ of short samples and $16-43 \%$ for long samples. The high percentage of the difference between analytical and experimental values is due to the flexibility of structures. When comparing the design (modeling) and experimental samples, the value of the critical load is within $10-12 \%$, which determines the finding of the correction coefficients of the working conditions for leveling of this difference.

These structures should be considered as concrete filled steel tube structures and steel reinforced concrete structures, taking into account the co-operation of all materials. The application of calculation formulas for steel reinforced concrete is possible if all physical and mechanical properties of the newly created structure are taken into account. The development of this problem requires a detailed study and development of an analytical description of the actual work of the structure.

Table 2: Comparison of the calculation results, experimental researcher and computer design

\begin{tabular}{|c|c|c|c|c|}
\hline \multirow{2}{*}{\multicolumn{2}{|c|}{ Name of characteristics }} & \multicolumn{3}{|c|}{$\begin{array}{l}\text { Critical effort of distruction of a sample } \\
\mathrm{N}_{\mathrm{cr}}, \mathrm{KH} \text {, obtained: }\end{array}$} \\
\hline & & analytically & experimentally & $\begin{array}{l}\text { MCE } \\
\text { (ITU) }\end{array}$ \\
\hline \multicolumn{2}{|c|}{ Steel pipe shell } & 24,8 & 22,3 & 24,53 \\
\hline \multicolumn{2}{|c|}{ Polystyrene concrete } & 19,78 & 18,64 & 23,00 \\
\hline \multicolumn{2}{|c|}{ LSTK profile } & 9,3 & 8,7 & 9,87 \\
\hline \multirow{2}{*}{$\begin{array}{l}\text { Concrete } \\
\text { filled steel } \\
\text { structure } \\
\mathrm{L}=400 \mathrm{MM}\end{array}$} & $\begin{array}{l}\text { Load on the } \\
\text { whole section }\end{array}$ & 44,58 & 48,5 & 51,83 \\
\hline & $\begin{array}{l}\text { Load on con- } \\
\text { crete }\end{array}$ & 19,78 & 46,0 & 52,17 \\
\hline \multirow{2}{*}{$\begin{array}{c}\text { Steel rein- } \\
\text { forced struc- } \\
\text { ture } \\
\mathrm{L}=400 \mathrm{MM}\end{array}$} & $\begin{array}{l}\text { Load on the } \\
\text { whole section }\end{array}$ & 53,88 & 72,2 & 81,89 \\
\hline & $\begin{array}{l}\text { Load on con- } \\
\text { crete and pro- } \\
\text { file }\end{array}$ & 29,08 & 60,1 & 68,16 \\
\hline \multicolumn{2}{|c|}{ Steel pipe shell L=1500мм } & 24,8 & 26,1 & 28,02 \\
\hline \multirow{2}{*}{$\begin{array}{l}\text { Concrete } \\
\text { filled steel } \\
\text { structure } \\
\mathrm{L}=1500 \mathrm{MM}\end{array}$} & $\begin{array}{l}\text { Load on the } \\
\text { whole section }\end{array}$ & 44,58 & 45,3 & 48,63 \\
\hline & $\begin{array}{l}\text { Load on con- } \\
\text { crete }\end{array}$ & 19,78 & 42,1 & 45,20 \\
\hline \multirow{2}{*}{$\begin{array}{l}\text { Steel rein- } \\
\text { forced struc- } \\
\text { ture } \\
\mathrm{L}=1500 \mathrm{MM}\end{array}$} & $\begin{array}{l}\text { Load on the } \\
\text { whole section }\end{array}$ & 53,88 & 64,5 & 69,21 \\
\hline & $\begin{array}{l}\text { Load on con- } \\
\text { crete and pro- } \\
\quad \text { file }\end{array}$ & 29,08 & 52,3 & 56,14 \\
\hline
\end{tabular}

\section{References}

[1] Leshchenko M.V. Teplotekhnicheskiye svoystva stenovykh ograzhdayushchikh konstruktsiy iz stal'nykh tonkostennykh profiley i polistirolbetona / M.V. Leshchenko, V.O. Semko // Inzhenernostroitel'nyy zhurnal, 2015. - №8. - P. 44-55. - DOI: 10.5862/MCE.60.6.

[2] Storozhenko L.I. Trubobeton: Monograph / L. I. Storozhenko, D. A Yermolenko, O. I. Lapenko. - Poltava: PoltNTU, 2009.

[3] Kinin A.I. Konstruktsii iz stal'nykh trub zapolnennykh betonom [text] / A.I. Kinin, R.S. Sanzharovskiy, V.A. Trul'. - Moscow: Stroyizdat, 1974.

[4] Storozhenko L.I. Stalezalizobetonni konstruktsiyi. Navchal'nyy posibnyk / L.I. Storozhenko, O.V.Semko, V.F. Pents // PNTU, 2005

[5] EN 1994-1-1. Eurocode 4: Design of composite steel and concrete structures - Part 1.1: General rules and rules for buildings, 2004.

[6] EN 1994-2. Eurocode 4: Design of composite steel and concrete structures - Part 2: Bridges, 2003.

[7] Storozhenko, L. Stability of compressed steel concrete composite tubular columns with centrifuged cores / Storozhenko, L., Butsky, V., Taranovsky, O. // Journal of Constructional Steel Research. - Proceedings of the 1998 2nd World Conference on Steel in Construction; San Sebastian, PR, USA; 11 May 1998 to 13 May 1998. - Volume 46, Issue 1-3, Apr-Jun, Page 484.

[8] Hasenko A.V. Causes of the eccentric compression reinforced concrete elements fixed joint stanchion and rafter gable frame of agricultural buildings / A.V. Hasenko, I.A. Yurko, O.G. Fenko, P.A. Yurko // The International Scientific Periodical Journal "Modern Technology and Innovative Technologies". - Germany: Karlsruhe, 2017. - Issue №2, Vol.2. - pp. 126 - 129. - DOI: 10.21893/2567-5273.2017-02-02-033.

[9] Dębski H. Application of fem in the analysis of the structure of a trailer supporting frame with variable operation parameters / H. Dębski, G. Koszałka, M. Ferdynus // Eksploatacja i Niezawodnosc - Maintenance and Reliability. 2012. - Vol. 14, № 2 - P. 107 - 114. DOI: dx.doi.org/10.17531/ein.

[10] Beicha D. Effective transverse elastic properties of unidirectional fiber reinforced composites [Text] / D. Beicha, T. Kanit, Y. Brunet, A. Imad, A. E. Moumen, Y. Khelfaoui // Mechanics of Materials. 2016. - Vol. 102. - pp. 47-53. - DOI: 10.1016/j.mechmat.2016.08.010.

[11] Bishnu P. A new method of applying long-term multiaxial stresses in concrete specimens undergoing ASR, and their triaxial expansions [Text] / P. G. Bishnu, K. P. Daman // Materials and Structures - 2016. - Vol. 49 (9). - pp. 3409-3508. - DOI: 10.1617/s11527015-0734-z. 